\title{
Pengembangan Nilai Florence Nightingale Dalam Pendidikan Keperawatan Di Indonesia
}

\author{
Achir Yani S. Hamid
}

Florence Nightingale dikenal sebagai perawat dan theorist pertama yang memiliki body of knowledge keperawatan. Nightingale menekankan fokus intervensi keperawatan adalah membuat lingkungan yang kondusif bagi manusia unntuk hidup sehat. Sebagian besar dari pemikiran Nightingale masih relevan dengan pendidikan keperawatan di Indonesia pada masa sekarang maupun yang akan datang.

Kata kunci : Teori, profesi keperawatan, perkembangan disiplin.

Florence Nightingale has been recognized as the first nurse theorist in development of nursing as a profession which its nursing body of knowledge. Nightingale emphasizes that the focus of nursing intervention is to make the environment to be conducive for healthy living of individuals. Most of Nightingale's thoughts are still relevance to present and even for future nursing education in Indonesia.

Key words : Theory, nursing profession, development of discipline. 